Article

\title{
Social Involvement of Polish Family Businesses
}

\author{
Aurelia Bielawska (D)
}

check for

updates

Citation: Bielawska, A. Social Involvement of Polish Family Businesses. Sustainability 2021, 13, 9484. https://doi.org/10.3390/ su13179484

Academic Editors: Danuta Zawadzka and Ermanno C. Tortia

Received: 31 May 2021

Accepted: 16 August 2021

Published: 24 August 2021

Publisher's Note: MDPI stays neutral with regard to jurisdictional claims in published maps and institutional affiliations.

Copyright: (C) 2021 by the author. Licensee MDPI, Basel, Switzerland. This article is an open access article distributed under the terms and conditions of the Creative Commons Attribution (CC BY) license (https:// creativecommons.org/licenses/by/ $4.0 /)$.
Faculty of Economics, Finance and Management, University of Szczecin, 71-101 Szczecin, Poland; aurelia.bielawska@usz.edu.pl

\begin{abstract}
Social involvement of enterprises, i.e., sharing wealth with those in need, can be spoken of only in the case of owner-managed family firms (FB). These companies account for two-thirds of all enterprises in the global economy; they contribute to the stability, development, and continuity of the existence of the economies of many countries. However, the sustainability of the existence of individual FBs is often threatened. Social engagement of owners and preparation of successors are the appropriate retort as they affect the transgenerational sustainability of these enterprises. The purpose of this study is to identify the causes, scope, forms, and beneficiaries of social engagement of Polish FBs. The study uses the Delphi method implemented in three stages: (1) selection of experts; (2) collection of information; and (3) development and interpretation of research results in the context of adopted research questions, research objective, and research hypothesis. The results of the study confirm that FBs make an important contribution to sustainable social development at the micro level. The social engagement of FBs brings benefits to both beneficiaries and donors, responds to genuinely existing needs, and supports the cross-generational sustainability of companies.
\end{abstract}

Keywords: family businesses; CSR; social involvement; scope; reasons and forms of social involvement; charity; philanthropy; impact investing; longevity

\section{Introduction}

In Poland, the market economy, and with it, family businesses (FBs), after many years of non-existence for political reasons, were reactivated in 1989. Under the previous economic system, FBs operated as a non-socialized economy and were treated as an inferior part of the economy. The political transformation was not favorable to them either. According to Eris-the founder and co-owner of Dr Irena Eris FB- “Today it is called a private company, but once it was just a craft. People who set up their own businesses were not supported by the state and it was not socially accepted" [1]. Despite the passage of years, a part of society not only still treats FBs with prejudice, but also has doubts about the nobility of their motives for social activity [2]. The influence of economic systems, legal systems, and culture on the assessment of the families of FB owners and the FB sector is noticeable not only in Poland [3].

Being raised in the system of centralized economy means part of society still has a modest knowledge of Polish FB; the owners of these enterprises are not always appreciated for this reason and do not always speak about it with pride. Piszczek-an FB founder and co-owner-wrote: "A family business is identified with something not very big and not serious. There is no prestige, no facilitations, no state support" [4]. The intention of this article is, among other things, to reduce the shortage of knowledge concerning FBs.

FBs are unique businesses. This uniqueness stems from the integration of family life and business [5], resulting in an organization that has several important and unique characteristics that distinguish FBs from non-family businesses. The objectives and principles of FBs are different from non-family businesses. In the literature, there is no consistency of assessments regarding the influence of family on the effectiveness of FB activities; both positie and negative assessments are presented [6]. The social involvement of these 
companies, which is the subject of the research presented in this article, is also assessed ambiguously [2].

The following research questions were formulated to explore the social engagement of Polish FBs:

RQ1: What are the reasons for FB's social engagement?

RQ2: Does social involvement only apply to beneficiaries in the country, or does it go beyond national borders?

RQ3: Is the social involvement of FB respondents a philanthropic or charitable activity?

RQ4: How do FB owners behave when faced with macroeconomic risks caused by the COVID-19 pandemic?

RQ5: Does the social involvement of Polish business families benefit donor families?

The aim of the research is to obtain answers to the presented research questions, which should allow us to understand the social involvement of Polish FBs, identify the causes, scope, forms, and beneficiaries of this involvement, and explain the relationship of charity with the longevity of companies and business families.

\subsection{Research Hypothesis}

FB achieves financial success and a competitive advantage determining its multigenerational longevity if it has not only adequate material resources, but also social resources, i.e., support from the family, a successor, a team of competent and committed employees, and good social relations with stakeholders.

\subsection{Working Method}

The study is based on systematic analysis of literature and empirical research. The result of the analysis of literature was the formulation of the five research questions. The empirical research was conducted using the Delphi method in the period January to April 2021. The owners, co-owners, and board members of family businesses (FB) were taken as experts. The research was conducted in three stages. In the first, the selection of experts was made on the basis of studies of information contained in FB's websites, business reports, sustainability reports, published interviews, and speeches at scientific conferences. The criterion for the selection of experts was the condition of having at least ten years of experience in managing a socially engaged family business. In total, 43 FBs were included in the research. The aim of the second stage of the research was to obtain answers to the research questions listed in the Introduction. The source material for the empirical research included interviews in the form of questionnaires, telephone conversations, and the so-called "white interview". The third stage of the research included the analysis and interpretation of the research results in the context of the adopted research questions, research objective, and research hypothesis.

The research allowed us to obtain answers to the presented questions, realize the goal, and positively verify the research hypothesis. This research makes a conceptual and empirical contribution to the understanding of FB social involvement, including the impact of this involvement on the over-generational sustainability of these companies and entrepreneurial families.

The research study was initiated by explaining the qualitative factors of FB that determine their distinctiveness, describing the concepts and types of social commitment of these companies, clarifying the concept of philanthropy and charity. The theoretical basis of the research is the CSR model, sustainable family business theory (SFBT), impact investing model, and stakeholder theory.

The article consists of five sections. After a brief introductory review and literature study, the research findings, discussion, and conclusion are presented.

\subsection{Research Limitations/Implications}

The main limitations of the presented study result from the adopted method, based on the analysis of experts' answers to the mentioned research questions. The research 
method was adapted to realize the assumed purpose of the work and to verify the research hypothesis. Experts from 43 FBs participated in the research. Due to the modest number of businesses included in the study, the author is cautious about the interpretation of the obtained results and the possibility of their generalization. Moreover, the author is aware of the fact that the article does not exhaust the research problem undertaken and is only a contribution to further research. However, the results of the research are a source of information and inspiration for business practice; they can be used both by the owners of FBs and the representatives of business environment institutions supporting their operation. The research highlights the diversity of FBs and factors conducive to their longevity and presents the social involvement of Polish FBs in a way that has not been used so far in the literature available to the author. They indicate the influence of the form of social involvement on the over-generational sustainability of FBs.

\section{Theoretical Background and Literature Review}

FBs dominate the economic landscape worldwide, accounting for two-thirds of all enterprises in the global economy, generating approximately 70-90\% of annual global GDP and creating 50-80\% of jobs [7]. Available data show that families (i.e., one or many families) own the majority of European micro, small, and medium-sized enterprises (SMEs). For example, 93\% of Italian manufacturing companies with fewer than 50 employees are family owned. Research shows that $27 \%$ of European listed companies are controlled by a family group [8]. According to Grant Thornton research, FBs in Poland account for $75 \%$ of the total number of enterprises and produce approximately $2 / 3$ of the Polish GDP, stimulate economic growth, and strengthen national entrepreneurship [9].

In studies conducted in Poland, various definitions of the FB concept are adopted, and this is the reason why it is not known exactly how many enterprises belong to this category [10]. Publications report the share of these companies ranging from 36 to $75 \%$ of the total number of enterprises [9]. The lack of a uniform definition of the concept of FB is a common phenomenon in the literature and in practice, which is not surprising in the situation of the diversity of these companies occurring in practice [5,8,10-12]. Therefore, there is a need to clarify the concept of FB adopted in the presented research.

The lack of an agreed definition also applies to the concept of social involvement. This concept has been known in practice and in the literature for a long time; however, the way it is understood is constantly changing. In this case, too, there is a need to clarify this concept for the purposes of the present research.

\subsection{What Distinguishes a Family Business?}

FBs have several unique resources that are referred to as familiness. Familiness refers to the behavioral characteristics of the family that distinguish it from other types of business owners [5,9-11]. These characteristics arise from the systemic interactions of the family, the individual family member, and the business and are a consequence of: the family's involvement in ownership, management, and control; and specific goals and values arising from the family's influence and the organization of the business [12-14].

For the family entrepreneur, "all the eggs are in one basket"-i.e., in the company, and the fate of the company is quickly aligned with that of the family. The consequence of this is that these companies have a specific system of stakeholder relations. Another peculiarity of FBs is that financial goals are not the most important for them; intangible factors motivated psychologically are more often predominant. FBs value intangible assets more than financial opportunities [15].

Observations of centenarian FBs in the United States of America (representing 0.5\% of the total number of companies) and in France (Association of long-lived companies, Henokiens, Paris, France) have shown that their longevity is mainly determined by shared values, a strong sense of mission and corporate culture, a mind-set based on respect for a set of values, and a long-term vision of business management [16,17]. In an effort to prevent FBs from becoming extinct, the next generations must be encouraged to participate 
in the enterprise; each generation must renew its values and mission so that participation in the effort is meaningful to the younger generation [18].

Almost all enterprises start as FBs [19]. The family business sector is growing rapidly and the importance of these enterprises in the economies of many countries is increasing $[9,20,21]$. The lack of an agreed definition of FB in research conducted in different scientific centers, not only in Poland, means that both their theoretical and empirical contributions can be compared only to a limited extent [12,22]. Nevertheless, it is justified to study the socioeconomic conditions in which these companies operate in order to deepen the knowledge of how family enterprises and business families function in different countries and with what effects. Through such research, it is possible to transfer, with prudence, experience between countries and strengthen the development of the global economy.

The definitional dilemma means that the concept of FB on which this publication is based needs to be made explicit: a family business is an enterprise financed and controlled by a family with the intention of passing it on to future generations. The classification of a company as a family or non-family business is not determined by its size, nor by its organizational and legal form, neither by whether it is privately or publicly owned. It is important what characteristics the FB has as a social organization; this depends, among other things, on the degree of identification of family members with the business, on intra-family relations, and on the way the family manages and controls its business. The family exerts a strong influence on the perpetuation and transmission of entrepreneurial behavior, which is particularly evident when it is seen as an institution that unites its members while supporting or limiting the choices available to family members. The family is a carrier of universal, traditional values that are transferred from the family to business. Family values create the image of the company, which becomes an integral part of its identity and, as the experience of countries with a long history of market economy indicates, foster its longevity [18]. Regarding the importance of family values in Polish FB, Śliboda-president and owner of FB Marco-stated that "professional competence can always be supplemented, but changing the value system may not be feasible" [23].

Regardless of the FB's age, the decisions of company founders and their successors are modelled by family influence $[21,24]$. Consequently, succession has received much attention in both literature and practice. Many researchers expose the importance of succession as a factor that enables the company to maintain control over generations $[12,25,26]$. In the researchers' assessment [27], succession is the most important feature of FBs, distinguishing them from non-family enterprises. According to the same researchers, the process of preparing the successor is the most important factor strengthening FB. Well-prepared and -implemented succession can become a stimulus shaping the competitive advantage of FB. This is due to the fact that the successor is prepared by the doyen over a long period of time-sometimes from early childhood-to acquire the knowledge and specific skills necessary to manage the FB. Sosnowski-the successor of FB KROSS—said he felt that the company founded by his father in 1990 was a kind of additional family member, "a younger brother by 2 years". He has been connected with the company since childhood. Already, as a child, he visited production halls and warehouses. Later, he worked in the customer service, human resources, and debt collection departments. Since 2012, he has been working for the company on a permanent basis [28].

In the literature, succession is sometimes evaluated critically. According to [6], FBs are burdened with a tendency towards nepotism, preferential treatment of family members, entrusting them with positions regardless of their competence. Family members are treated, in many respects, better than non-family employees. The result can be an unprofessional entrepreneurial culture that reduces company performance. Excessive compensation or special dividends paid exclusively to family members reduce the self-financing capacity of FB. To conclude: the sustainability of FBs' existence is threatened if family members, without adequate competence, play a key role. Nepotism negatively affects the company's ability to compete and survive. Other authors, although also recognizing the adverse 
effects of succession, consider that the succession of the company has more advantages than disadvantages [29].

Transgenerational transfer of company assets as the most important objective of FB management is expressed by many FB owners. Orfinger-the co-founder and co-owner of FB Dr Irena Eris-said: "My most important life goal is for the company to remain after me as an heirloom. We have built a strong brand and we want it to exist continuously, so that my children, my grandchildren and my great-grandchildren benefit from what the company builds, as beneficiaries, but successively. I would like it to last as long as possible, for decades, hundreds of years" [30].

Business succession is a complex, multistage, multidimensional process and, unfortunately, unsuccessful in the vast majority of cases. Only 30\% of FBs pass from the first generation to the second generation of the family, $10-15 \%$ to the third generation, and $3-5 \%$ to the fourth generation [29]. If we agree that FBs play an important role in the social and economic life of the country and contribute to the sustainable development of the country and society, it is necessary to look for solutions that can increase the chances of successful succession and ensure the sustainability of these enterprises' existence. The experience of enterprises with a long history can be a good model [16-18,31]. The literature presents research results indicating that the longevity of small enterprises-most FBs belong to this group-is fostered by the creation of multifaceted networks of cooperating companies and the ability to quickly adapt to the conditions of the competitive environment [32].

FBs endure difficult periods of recession and stagnation more easily, and one of the main reasons for their vitality is the owners' sense of personal responsibility for the company's image. Family-managed companies are perceived as more reliable, responsible, and doing their job with the utmost commitment [31].

Strengthening the family position in the company has advantages but also disadvantages $[6,29]$. The form and extent of family involvement depends, among other things, on factors that determine the propensity of family members to preserve socioemotional wealth, i.e., the non-financial aspects of the firm that satisfy the affective needs of the family, such as identity, the ability to influence the family, and the perpetuation of the family dynasty [5,31].

FBs have limited ability to raise capital from external sources, because they avoid sharing control of the business with non-family members, they are risk averse, and the size of these firms typically prevents them from raising capital in the financial market. As a result, these firms do not have access to the traditional financial markets that are available to many non-family firms and large FBs that have 'diluted' intra-family ownership. This attitude makes it difficult to compete in the market [22]. The strength of family businesses is what the strength of a healthy family is: honesty, selflessness, mutual trust, and the commitment often of all its members to a jointly adopted goal. Thus, the family and the company are closely linked; this relationship partially immunizes FB against crises [15]. The strong emotional bond of the family with the company and the desire to pass it on to the next generation sometimes causes the family to fight for their business with more passion than in the case of non-family companies. One consequence is that crisis management in FBs often differs from crisis management in non-family entities. For example, often particularly close relationships occur with employees who have been with the company for a long time, with time becoming "par-family" relationships. The identification of employees and their attachment to the company is reciprocated by care from the owners' family [15]. In this way, in FB, human capital is created, which, in the opinion of many owners, should not be threatened or destroyed even in crisis situations. According to Abbas [33], in the face of crisis situations, human resource management, which is one of the three pillars of the enterprise, must change. In other studies [34], authors suggest the use of financial and business organizations and companies for creative methods of managing employees, adapted to pandemic conditions, increasing the chances of survival. Other scientific reports-for instance, on the evolution of the HIV pathogen in six Latin 
American countries-point to the possible dire consequences of neglecting the welfare of the population during a pandemic [35].

The existence of interdependence, especially in financial terms, between the family and the company means that the family provides a financial buffer for the company in a state of emergency [15]. Thanks to this relationship, companies can survive times of crisis better or longer than non-family companies. Of course, it is a condition that the company makes a profit from its business in the long term, and that the policy of distributions to owners is restrained. Studies have shown that the retention of profits in the company is a common practice in FBs, which allows them to survive temporary perturbations in finance and, at the same time, allows them to maintain a certain independence from the financial market and especially from banks [9,15,21].

In situations of high risk, such as those occurring during systemic changes or pandemics, the way of managing FBs' finances becomes particularly important, helping-in the short term - to survive the most difficult situations. The systemic changes that took place in Poland in the 1990s were better survived by FBs that were more oriented to the continuity of their activities and less profit-oriented, more traditional in their behavior, risk averse, and less greedy. However, it is worth noting the long-term effects of such behavior, namely the reduction in profitability characteristic of FBs once the company is taken over by the second and further generations, and the decline in profitability as the company ages. With the priority of preserving the legacy of earlier generations, FB boards make investment decisions that are less risky and therefore also less profitable for fear of giving up some of the market opportunities [9].

According to Swiss researchers, FBs are predestined to become champions of innovation. By combining innovation and tradition, these companies invent new competitive strategies. Thanks to their long-established culture, FBs understand tradition extraordinarily well, and because they are "rooted" in the region, they also have the capacity to adapt to market needs [31].

FBs - as with all other businesses-need to compete in the market, and so they need to invest in innovative and risky ventures. According to D. Bain: "Century Club companies are not dinosaurs. Contrary to popular belief, these companies are very good at innovating and changing. However, we do it from a position of strength" [17]. By neglecting to innovate by producing products that are easy to copy, these companies would run the risk of their competitors putting them out of business.

The particular sense of responsibility for the country's economy in Polish FBs is evident against the background of the opinions of enterprises from the world and Central and Eastern Europe. Polish entrepreneurs much more often-even $90 \%$ of those surveyed by the Institute of Family Business (IBR), compared to an average of $70-80 \%$ in the worldemphasize the role of FBs in building the economy of their country [36].

Research by Grant Thorton [9] has shown that, in times of good economic stability, Polish FBs bring similar returns to investors as non-family companies, while in times of market turmoil, they give higher profitability. EBITDA profitability over 12 months (Q4 2019-Q3 2020) for family companies was 12.3 per cent and, for non-family companies, 10.8 per cent. Profit over the period was 2.7 per cent in FBs, while for the other companies, a loss of (-)1.5 per cent was recorded. Even greater differences can be seen in the case of the return on equity (ROE), which was 5.1 per cent and (-)2.2 per cent, respectively. According to the researchers [9], investors put a lot of trust in family companies, especially in difficult times, such as pandemics; this is evidenced by the value of the WIG-Family companies index developed by Grant Thornton experts. WIG-Family is a Warsaw Stock Exchange index of 10 family-owned companies listed on public markets. In the period January 2015-February 2021, the WIG-Family value increased by approximately 40 per cent, while the value of the index of the 20 largest remaining companies in the Warsaw Stock Exchange Index (WIG-20) declined by about 16 percent over the same period. This trend continued in the period February 2020-February 2021 [9]. 
The Grant Thorton Report [9] shows that, among FBs listed on the Warsaw Stock Exchange (WSE), there are still few that have the issue of generational succession resolved. This can be seen, for example, in the ownership of the companies analyzed [9]. Although many of the founders and main shareholders of FBs are now approaching retirement age and will soon have to manage the problem of succession, only 17 per cent of these companies already have shares in the hands of at least one successor. Successors are also rarely present in the main bodies of companies. Currently, only one in six FBs has a representative of the successor generation sitting on the board of directors, and one in five on the supervisory board. Meanwhile, as many as half the companies have a doyen on their management and supervisory boards as the sole representative of the family (55 and 48\%, respectively). Research results [6,9] indicate that the prospect of succession causes FBs to make long-term investments more often than non-family companies, and (Yes, it should be) thanks to this, they cope better than other companies in periods of market turbulence $[9,37]$. Lack of foresight in preparing successors to take over the company's management may indicate future problems with the sustainability of many FBs.

FBs have specific characteristics that distinguish them from non-family businesses due primarily to the influence of the owners' family on their business. The business is the family's source of income. Caring for the financial security of the family, the owners care about the financial security of the business. Financial profit is not the most important thing for them; more often, intangible psychologically motivated factors prevail. The primary goal of FB is to pass the business to a successor. This objective influences the owners behavior: they care about preserving the family values brought to the company, about the company's good image among stakeholders, good relations with the environment, and long-term relations with employees. The intention to transfer the business to the successor means they make less risky and long-term investments more often than nonfamily companies and thus stabilize the economic development of the country.

\subsection{The Concept of Corporate Social Commitment}

For several decades now, the debate on proper relations between enterprises and society has centered on the topic of corporate social responsibility (CSR). CSR refers to the impact of a company's activities on society and the environment. The precursor of this research in German literature was von Carlowitz, the author of the work entitled "Sylvicultura Oecultura" published in 1713 [38].

This area of enterprise management is relatively new in Poland. CSR ideas were implemented in Poland in the late 1990s and early 2000s by corporations originating from countries with a longer tradition of market economy. It was thanks to them that the idea of sustainable enterprise development was put into practice in Poland.

Under the conditions of the previous regime, social involvement of enterprises was realized as the social policy of the state. The assumptions of this policy were developed by the government and its administration. Enterprises, which were the property of society, performed the assigned tasks. They guaranteed access to health care, education, culture, recreation, and housing. Social policy was designed to ensure social justice through fair distribution of income (egalitarian wages). An extensive system of social benefits was intended to raise the quality of life and compensate for low wages. The benefits-financed from the state budget-were low, but they fostered a sense of security in the state [39].

CSR ideas transferred to the Polish economy represent a new quality of social involvement of enterprises. Studies have shown that FBs implement the CSR model seeking to preserve socioemotional wealth and firm survival $[24,40]$. The same research also demonstrated that the socially responsible behavior of FBs is positively correlated with the number of family members in the governing bodies and environmental conditions conducive to their growth.

The Anglo-American term CSR was first used in the literature in 1953 by Bowen [41]. As Beckman et al. [42] argue, resulting from pressure from stakeholders in business organizations, Friedman's classic claim that "the only responsibility of business is to multiply 
profits" has been replaced by the claim: "the only responsibility of business is to create values". According to Bowen [41], companies should not only be responsible for their bottom line, but also for achieving the goals and values expected by stakeholders. According to Altenburger and Schmidpeter, this idea was already known in ancient Greece [43].

Drucker, in turn, draws attention to the change in social expectations towards business and stresses that it is no longer just about reducing its negative impact on the environment, but doing something useful for society without being forced to. Drucker stressed that social problems are real challenges for government, and that the function of business is to satisfy social demand while benefiting itself [44]. FB's social involvement is, therefore, the adoption of some of the state's responsibilities by these companies.

Many companies worldwide have found it necessary to integrate CSR principles into their strategic programs. CSR can be an important factor supporting the development of FB [45-47]. The beneficial impact of CSR on the company's activities is confirmed by Śliboda-president and owner of FB "Marco" — saying that: "we do it for family values, but it helps us a lot in business" [23].

Attempts to define the concept of CSR have been made for many years. All of them are based on the ethical and moral responsibility of enterprise, which goes beyond legally defined behavior $[8,48,49]$. The multifaceted nature of this concept makes it difficult to explicitly define. In 2011, the European Commission (EC) proposed a new definition, according to which "corporate social responsibility means the responsibility of a company for its impact on society". At the same time, the EC listed the types of enterprises, including FB, for which the implementation of CSR principles may be particularly beneficial [50]. Creating common values for the company's owners/shareholders, employees, as well as other stakeholders allows one to identify, prevent, and mitigate the impact of negative effects of the company's activity, which is a premise of its social involvement and, as the experience of century-old companies indicates, longevity [17].

As shown by the survey conducted by IBR, FBs are distinguished by the way they look at their social responsibilities, and this particularly applies to Polish companies. Eighty seven percent of companies surveyed declared a sense of obligation to support social initiatives in their environment. A similar sense of duty is declared by $66 \%$ of companies in the CEE region and 59\% globally. Eighty three percent consider it their duty to support employment in their region, compared to $74 \%$ in CEE and 76\% globally. More than 50\% declare a high level of commitment to CSR and $81 \%$ say they are involved in philanthropic activities [36].

One of the first CSR models, constituting a framework for implementing this concept in enterprises, is the Carroll's model [51]. In this model, the author assumed that CSR consists of four areas of responsibility-economics, law, ethics, and philanthropy-and presented them in the form of a pyramid. These types of responsibility were already known before, but it was not until Carroll systematized them in a hierarchical system in which ethical and philanthropic functions took a prominent place.

According to Carroll's model, the primary area of CSR is economic responsibility for the sustainable existence of one's own company, followed by legal responsibility. Based on these two areas, Carroll identified a third-in his view, the most important-area of responsibility, namely ethical responsibility of the enterprise for taking into account current legal norms and social values, as well as one's own entrepreneurial culture.

As the fourth area of CSR, philanthropic responsibility was mentioned. According to Carroll, this area of CSR includes a form of voluntary commitment in the sense of the common good that is not prescribed by law and is not demanded by society [51]. Responsibility in this meaning is referred to in contemporary literature as corporate social commitment $[45,52-54]$. Table 1 presents social involvement as a component of Corporate Social -Responsibility and types of this involvement. 
Table 1. Social involvement as a component of CSR and types of this involvement.

\begin{tabular}{c|c|c}
\hline \multirow{2}{*}{$\begin{array}{c}\text { Corporate } \\
\text { Social-Responsibility } \\
\text { (CSR) }\end{array}$} & $\begin{array}{c}\text { Social } \\
\text { Involvement }\end{array}$ & Charity \\
\cline { 2 - 3 } & \multicolumn{2}{|c}{ Ethics } \\
\cline { 2 - 3 } & Law \\
\cline { 2 - 3 } & Economics \\
\hline
\end{tabular}

Corporate social responsibility is assessed ambiguously in the academic literature. Supporters believe that companies have a moral obligation to support the environment in which they operate. Opponents are of the opinion that social activity consumes the enterprise's resources intended for the realization of its business goals and does not create shareholder value. A representative of the skeptical attitude towards corporate social responsibility is Karnani [55]. However, his criticism applies only to enterprises managed by hired managers. He explains his critical attitude as follows: "the directors are hired to maximize profits. Even if executives wanted to give up some of the profits to society, they could expect to lose their jobs if they tried-and be replaced by managers who would reinstate profit as a top priority. This is one of the reasons why so many companies talk a lot about social responsibility but do nothing - a tactic known as greenwashing. FB is a different story. If an owner-operated business chooses to accept less profit in order to increase social well-being it is admirable and desirable for successful leaders to donate a portion of their personal fortunes to social purposes. In fact, many owners donate significant amounts of the money they earn from their investments to help fund charity organizations or otherwise improve social welfare". Sharing Karnani's view, it is assumed that corporate social responsibility can only be talked about in the case of FB.

The local character of FB involvement creates a chance for the charity to reach those most in need in a way that is not merely marketing. The nature and scope of the assistance provided, as revealed by the author's research, indicate that, in many cases, without the help of local FB, those in need would be left alone with their problems.

Over the years, FBs social involvement has changed and transformed, with donor families looking for new ways to make sure their donations are effective. According to views presented in the literature $[44,53,54]$, when engaging socially, business families should not act only in response to the needs of beneficiaries, but should align their actions with their own business plans and with the expectations of future family leaders (successors). Such a model of behavior encourages families to share their wealth and makes their activities effective and efficient. Drucker points out that a necessary condition for the company to engage socially is to behave in an economically responsible way, while the condition of effectiveness is that the company should not take actions beyond its own competence [44].

In publications, social involvement is considered philanthropic activity and as charity activity $[12,54]$. Although the basic principle, in both cases, is to help those in need, the form, modes of action, and effects are different. According to Both: "If philanthropy is treated as an investment based solely on love (philos) for humanity (anthropos), it is not surprising that many businesses see it merely as the pursuit of those super-rich. In the case of FB, it may be justified to take a more holistic and open perspective on the potential benefits of philanthropy, not only as an investment in society as a whole, but as a long-term investment in a healthy, sustainable business with which both family and employees feel a strong connection" [56].

Misciattelli delle Ripe, president of Actions Placement Agent and president of AIFO (Italian Association of Family Offices) believes that "the need to share wealth has changed from charitable giving to effective and focused multigenerational philanthropy that mobilizes all family members for a common cause. Philanthropy is an ideal way to strengthen family ties and ensure continuity between generations" [57].

Philanthropy is becoming more strategic and more practical, and different varieties of it have emerged [53]. Research findings presented in The Global Family Office Report 2019 indicate that $26 \%$ of families participating in the Campden Wealth for the Global Impact: A 
Power for Good 2020 said that it was worthwhile for them to invest in philanthropy, and $24 \%$ believe that incorporating sustainability leads to higher returns on investment [53].

The article assumes that social involvement of FB can take the form of philanthropy or charity. At the same time, the following definitions of these concepts are formulated:

Philanthropy is planned, far-reaching, and carefully thought-out behavior that results in benefits for beneficiaries and donors.

Charity is financial or material assistance that responds to current social needs.

The effect of philanthropy should be beneficial social changes, improvements in the quality of life of local communities or larger social groups. The literature $[44,53,54]$ expresses the view that philanthropic activity is an FB's investment. When investing their money, FBs should finance tasks that bring the best results for society and for the company. Such an expectation is especially important in the situation of the global socioeconomic crisis caused by the COVID-19 pandemic. The difficult economic situation results in less and less private capital to help. It is not easy to measure precisely the impact of FB's philanthropic activities on social challenges. However, these companies should start implementing and improving mechanisms to measure the impact, management and observation of philanthropic activities [58,59]. Impact Investing, defined by The Global Family Office as "investing with the intention of generating measurable environmental or social impact along with providing a competitive financial return", is adopted to evaluate the effects of philanthropy [53]. Impact investing is an investment strategy that aims to generate not only specific beneficial social or environmental impacts, but also financial returns for philanthropists. The primary task of impact investing is to help reduce the negative effects of economic activity on the social environment. Therefore, this strategy is considered an extension of philanthropy [53].

Kulczyk, the founder and president of the Kulczyk Foundation, entrepreneur, and philanthropist, claims that the approach to philanthropy differs from country to country. In Poland, people are reluctant to talk about philanthropic activities and domestic philanthropists are sometimes perceived negatively. This is because there is a perception that these are actions for show, which are only intended to cover up tax fraud or improve a company's image. As a result, businessmen are reluctant to talk about their social involvement, and moreover, they try to protect themselves from the flood of requests for help. This is why setting up foundations is so important and often used. Institutionalizing philanthropy helps to manage resources and funds so that effective and efficient aid can be provided. According to Kulczyk, philanthropy is a key element of family business [60].

Corporate social involvement involves the owner voluntarily sharing his assets with those in need. Such involvement may constitute charitable giving or philanthropic activities. Contemporary literature states that the need to share wealth is changing from charitable giving to effective and focused multigenerational philanthropy.

\section{FB Social Involvement in the Context of the Research Conducted}

Forty-three experts with at least ten years of experience in managing socially engaged FBs participated in the research. The experts' task was to answer the five questions formulated in the Introduction. The analysis of the answers obtained is intended to present the effect of the research objective and verification of the research hypothesis. The research results are presented in the form of answers to the research questions. To emphasize the scientific integrity of the conducted research, the answers are not only generalizations of the obtained results, but also include the most characteristic statements of the research participants.

\subsection{RQ1: What Are the Reasons for FB's Social Involvement?}

The results of the study clearly show that social involvement is the implementation of the values professed by the owner, the realization of emotional needs, and the desire to do something good not only for themselves but also for others. For many entrepreneurs, it is important to share with society a part of their own success in the long run. 
Śliboda—president and owner of FB Marco—stated that: Helping gives me great joy and it has been from the very beginning, it comes out of my DNA. Family values are at the basis of CSR activities in the company" and further, without quotation marks it is known that some people are more grateful, and others less, but this does not stop me from continuing to help. CSR brings tangible benefits to the company [23].

Siecińska-Jaworowska-president and co-owner of FB Suempol also sees her social involvement as an influence of family tradition. According to her: "Generations change, businesses are taken over by increasingly younger family members, but the values instilled by fathers, grandfathers or great-grandfathers remain unchanged/..../. Values such as a serious approach to one's duties, respect for work and respect for other people, caring for the environment, all this instilled in us by the owners from the beginning, form our philosophy of work. It is thanks to the instilled values that our company can develop, and today already the next generation passes these values on" [61]

Bieniaszewska - the owner of MB Pneumatyka — explains the motives of her charity work as follows: without quotation marks. In building my company in Sulechów, Lubuskie, I was helped by people from the region. This is our greatest capital. Our success depended on the level of education in the region and beyond. That is why I have been actively involved in cooperation with local secondary schools and universities for 10 years. We establish mechatronics classes, organize internships, support students by inviting them to placements and enabling them to create joint projects. Many of them are willing to work for us. Cooperation with universities is expanding beyond the region of Lubuskie [62].

FB Starak S.A. established the Starak Family Foundation, which offers young people the opportunity to participate in the Horizons Scholarship Program, which provides comprehensive support to male and female students from small towns who want to study at schools in big cities [63].

According to Roleski-co-founder and co-owner of FB Roleski-his company pursues its business objectives based on values and principles: reliability, honesty, care for employees, and building trust in customers and business partners. "In our case, social involvement or philanthropic activities are not a way to shape a positive image of the company, but result from a deep conviction of the necessity to support those most in need" [64].

Tarczyński-president of the board and co-owner of FB Tarczynski S.A.-said that: "The company is concerned about sustainable development, promoting healthy eating habits and an active lifestyle, and supporting local communities. The Barycz Valley region is particularly important to us. This is where we are, where we live and work, therefore we feel a great obligation to this place. The most valuable for the company, besides satisfied customers, are satisfied employees, therefore from the beginning of its operation the company has provided employees with friendly workplaces, opportunities for professional development and promotion, and a rich social package. The company provides, among other things, individualized training in the basics of management for all employees in managerial positions. In addition, it offers its employees, among others: the third pillar pension program, medical care, commuting to and from work, as well as free canteen with hot meals" [65].

Gratitude for the opportunity to learn and develop in their youth is the motive for the social involvement of people who have achieved wealth and already have something to share. Such persons include Kler-the owner of FB Kler-who supports musically talented youth, saying: "Someone once gave me a chance. Today it is my turn to share my success" [66].

\subsection{RQ2: Does Social Involvement Only Apply to Beneficiaries in the Country, or Does It Go beyond National Borders?}

FB's philanthropic activities are primarily local. These companies create and support domestic actions, although there are also examples of foreign action. The local scope of FB's social involvement is mainly due to their strong ties to the local community, even if the company is present in foreign markets. Ptaszek-co-owner of FB JMP Flowers-representing the sixth generation of the owners' family said: "Non-family businesses communicate their 
community involvement on TV programs, and FBs do a lot of good for the neighborhood community" [67]. JMP Flowers exports flowers to 26 countries, but is socially involved in Stężyca, where it has its headquarters. Ptaszek is the initiator and manager of the "English Club" project, an English language learning program for middle school students, in which 50 elementary and middle school students in Stężyca participate in English classes each year. JMP has subsidized the construction of a multipurpose sports field at an elementary school, co-financed the construction of the Education and Sports Center, and has co-financed a local football team for many years [67]. According to Siecińska-Jaworowskaowner of FB Suempol- the company tries to be a good employer and a good neighbor for the local community. In these relations, it offers assistance in financing local initiatives, e.g., supporting school competitions, sport events, supplementing scientific facilities. The company also supports financially other initiatives, both local and nationwide, e.g., it has subsidized the Catholic Youth Association, the municipal orphanage, the Amazon Foundation, and social welfare homes, financed purchases of medicines for sick children, sponsored the Patagonian Ears living in the Krakow zoo, and purchased an organ for the St. Michael Archangel parish in Bielsk Podlaski. FB Suempol's social involvement crosses the borders of the country. The company has also donated money for children in Ukraine and Belarus, and co-financed the reconstruction of the Polish Soldiers Cemetery in Belarus. According to the owner of FB Suempol, "all charity actions are the result of the desire to help in the environment from which the company grows. The real motivator to build good and lasting relations with the local community is the visible effect of the company's involvement and the joy it brings to others" [61]. Owners of small FBs spoke-during telephone interviews-about financial and in-kind support provided to students and their schools located in the town where the FB is based, which are often small towns or villages. These companies invite students from local schools and students of majors related to their business to meetings with their employees. This last activity is an example of "competence volunteering", which allows young people to learn about business from the practical side.

Śliboda-president and owner of FB Marco-said: The company's budget for the implementation of the "Marco-Helps" program (about 10\% of annual income year-on-year), is also contributed by employees, who donate for this purpose $1.5 \%$ of all financial gratuities received. The core values of FR Marco include, above all, working for the benefit of the local community. This "localness" is explained by the company owner as follows: "we are not able to help everyone, and one of the principles we follow is to get to know personally everyone we want to help and to create a mini-community that we will support [23].

"For many years" - says Roleski, the owner of FB Roleski-"we have been helping various institutions and non-governmental organizations: we support big ones, like The Great Orchestra of Christmas Charity or Caritas, but we are mostly engaged in helping the small ones, operating in local communities. We provide permanent in-kind support to, among others: St. Brother Albert's Shelter for Homeless Women from Krakow, Social Assistance Home in Nowa Dẹba or St. Kinga's Community Self-Help Home in Tarnów. In addition, at local festivals and picnics there is never a shortage of ketchups or mustards donated by us, they are an attraction for children and adults" [64].

Kulczyk established the Kulczyk Foundation to provide assistance to countries affected by poverty, natural disasters and various natural catastrophes. An example of the Foundation's involvement abroad is the preparation and publication of a report entitled "A bloody problem: Period poverty - why we need to end it and how to do it" containing an analysis of the menstrual health and hygiene (MHH) sector and an evaluation of the effectiveness of aid programs addressed to women. This report is a result of a collaboration between the Kulczyk Foundation and Founders Pledge [60].

\subsection{RQ3: Is the Social Involvement of FB Respondents a Philanthropic or Charitable Activity?}

Staniszewski-owner of FB Fjord Nansen, which manufactures outdoor clothing and equipment-has adopted a policy of providing assistance in the form of in-kind sponsorship, supporting travelers by offering them equipment to own or borrow for 
testing. In return, he expects information about the sponsorship to be published in a way chosen by the beneficiary. The company has supported many events and tourist and travel initiatives, including the expedition through the frozen Baikal in 2015, the Extreme Orienteering Rally "Harpagan", the mountain run in Silesian Park, the organization of the mountain meeting "Avalanches", as well as the yacht regatta in Puck. The company supported Piotr Bask in his bicycle expedition along and across South America, as well as one of the most famous Polish travelers, Aleksander Doba, in his solo canoe trip across the Atlantic. This is an example of philanthropic investment. The donor, while giving support, expects, in return, the popularization of his enterprise, hoping to increase its turnover and obtain capital to finance further travelers [68].

Philanthropic investment also includes supporting company employees and their families. This form of social involvement with emphasis that it is the most important form-or one of the most important forms - of charity was indicated by all experts. As examples of this form of involvement, the following were mentioned: integration meetings of company owners with employees and their families, increased standards of health and safety at work, additional health benefits, offers concerning pension provision, various options of combining work with family responsibilities, including childcare, e.g., own kindergartens, and financial support for employees and their families, who-through no fault of their own-found themselves in a difficult situation.

FB Tarczyński S.A. co-organizes and co-finances $80 \%$ of the summer vacations and language camps for the employees' children. The company is periodically visited by pupils and students as part of supplementary classes in vocational schools and universities on faculties related to food technology and automation [65].

\subsection{RQ4. How Do FB Owners Behave under Macroeconomic Risk during the COVID-19 Pandemic?}

During the COVID-19 pandemic, the FBs surveyed have been very active in providing humanitarian aid. This aid is adapted to the financial capabilities and type of activity of the donor. As part of the assistance, FBs subsidize hospitals to improve hospitalization conditions of patients, financially support the construction of hospices and special wards for COVID-19 patients, provide funds to hospitals for investment in medical equipment, or purchase equipment and donate it to hospitals.

In March 2020, the Kulczyk Foundation donated 20 million PLN to the Polish Lekarze Lekarzom (Doctors to Doctors) Foundation to purchase medical equipment to fight the COVID-19 pandemic [60].

FB Polpharma, in 2020, purchased 100 respirators for the health service [63].

Since the very beginning of the COVID-19 pandemic, Gierszewski-creator and founder of FB Drutex S.A.- - has been supporting Polish hospitals; so far, he has donated help worth approximately 3.5 million PLN. He is a co-founder of the foundation "Jesteśmy Razem. Pomagamy!" (We are Together. We help!) foundation, which he established together with other FBs, and the value of aid donated within its framework has already exceeded 50 million PLN [69].

FB Suempol provided assistance worth one million PLN to the District Hospital in Bielsk Podlaski, as well as financial donations to purchase necessary equipment for many medical units in other regions of the country [61].

At FB MARCO, all employees engage socially for at least $16 \mathrm{~h}$ a year. In 2020, the company allocated PLN 600 thousand for charitable purposes. In 2021, it has financed changes in the organization of the multispecialist hospital in Gliwice, so that the atmosphere of this clinic is patient-friendly [23].

FBs operating in the food service industry have provided meals from their own restaurant to hospitals for medical staff. During a pandemic, the priority for many FBs is to keep jobs. This is due to the principle held by these companies that profit is not always the most important thing. 
FB owners take various measures not to dismiss employees. Gołebiewski-the owner of FB T. Gołębiewski-in order to maintain almost 1000 jobs in his hotel chain, mortgaged his property for 30 million PLN, took a bank loan, and did not dismiss any employees [70].

A different solution was adopted by the owner of bicycle manufacturer FB Kross: due to the pandemic, he dismissed $25 \%$ of the 400 -strong workforce, and the remaining employees were employed on a 4/5th time basis from 1 April 2020. The redundancies were accompanied by severance pay and the promise of re-employment with the recovery of the bicycle market [28].

Experts also said that FB managements, in order to protect workers from COVID-19, reduced the number of workers simultaneously present in the company. They divided production workers into two groups working in shifts on a weekly basis. Office workers were also divided into two groups, with some working online and some onsite. This made it possible to maintain an appropriate distance between employees.

FBs adopting a socially responsible attitude towards their employees mitigate the social impact of the pandemic while benefiting from this commitment.

De Neve's research showed that 'happy employees are 13 percent more productive' [71].

\subsection{RQ5: Does the Social Involvement of Polish Business Families Benefit Donor Families?}

Social involvement of FB owners is a manifestation of family values; such activities strengthen ties and build family pride, as well as provide an element of pure satisfaction $[56,60]$. Family members who are unwilling or unable to take an active part in the work of the company can show their mettle and find a common ground right through prosocial activities. Younger generations can test their managerial skills on more neutral ground. Studies have shown that, typically, the area of assistance in which an entrepreneurial family engages is somehow related to their industry, family tradition, or specific life events. This helps to nurture family traditions of sharing with those in need and passing on the best not only to their immediate successors, but also to future generations.

FB initiatives for the benefit of local communities lead to a better perception of the owner families themselves among neighbors and friends, and result in raising the family's status in the environment. Observations of long-lived companies indicate that good relationships with the environment promote their longevity over generations.

Many FBs establish non-profit foundations. In addition to the foundation's mission to fulfill philanthropic motives, it is also a viable and long-term concept to secure company succession and defend against future business failures. Publications present the view that philanthropy is often the glue that holds the largest business families together. Philanthropy is a key element in maintaining strong family ties across generations, which further enables business growth by supporting multigenerational wealth transfer $[56,60]$.

\section{Discussion}

The decision of social involvement of the company, i.e., voluntary donation of a part of assets to the people in need, can be made only by the owner.

The study attempts to present the social involvement of Polish FBs, to determine the motives, scope, forms, and beneficiaries of this involvement, and to explain the relationship of philanthropic activity with the longevity of businesses and families of entrepreneurs. In Poland, corporate social involvement is a relatively new phenomenon. In the previous economic system, decisions on social activity were taken by the government and implemented by state-owned enterprises. In the current economic system-a social market economy-decisions concerning social involvement, i.e., sharing one's own wealth with other people and organizations, are personal decisions of entrepreneurs. FB's philanthropic activity lends it self very hard to research and scientific generalizations. Entrepreneurs do not want to talk about it. According to Kulczyk [60], it arises, among others, from the fear of "a flood of requests for help". In order to find out the specifics of FB social involvement, it was decided to refer to individual statements and assessments of owners, co-owners, and management board members of these companies. Source materials were 
obtained using the Delphi method. The sources of information were interviews in the form of questionnaires, telephone conversations, and the so-called "white interview". The aim of empirical research was to obtain experts' answers to the research questions listed in the Introduction. The obtained source material has been analyzed, and the research results have been interpreted in the context of the adopted research questions, the research objective, and the research hypothesis.

Some of the surveyed companies have been in business for generations and are successful, according to their owners [60,67], not only because of the business idea, but also because they see their social involvement as the mission of the company and the family. The realization of their own values in line with the family mission and tradition is the most frequently presented motivation for charity, but also a factor integrating donor families. Gratitude for the support granted at the stage of enterprise building and for the chance of development received in youth causes those successful persons to become financially involved in initiatives for the benefit of the region where the enterprise operates, and for the help received in youth, they repay the debt of gratitude by financially supporting talented youth.

FB's community involvement is not widely known to the public. It is known mostly in the community in which the FB operates. FBs act mainly for the benefit of the local community. The local character of the assistance provided means that entrepreneurs know the beneficiaries of their charity, therefore it is always assistance provided to people and organizations that genuinely need support. Donations granted to the local community are of various character and form. Entrepreneurs develop a strategy and budget for their social involvement. They refuse to provide support if they have doubts about the rationale for providing that support or if the donation is not in line with the adopted strategy.

The research carried out provided evidence that the social involvement of Polish FBs crosses national borders. Assistance is provided to the society both in Poland's neighboring countries and in African countries. The beneficiaries of this support are always people or organizations known to the donors. FBs conduct charity activities in the form of charity or philanthropy. All companies surveyed provided charitable assistance in response to the needs of society caused by the COVID-19 pandemic. A frequent form of assistance was the financing, at the request of parents, of expensive medical procedures and medicines saving the health and lives of children.

Philanthropy is a long-term activity that causes beneficial social change. The conducted research provided many examples of such activity. FBs finance English language learning for elementary school students in small towns and villages. Another example is family foundations supporting young artists through donations for education. FBs finance holidays for children from poor families.

The forms of FB social involvement are tailored to the needs of the beneficiaries and the financial capabilities and competences of the company-the donor. The market success of FB is, to a large extent, the effect of good relations with stakeholders: close relations with business partners, long-term relations with employees, visible participation in the life of local community, and readiness to help in various matters are the main premises of social involvement mentioned by the surveyed companies.

Companies, by engaging socially, if they choose an area close to their key competences, may give the beneficiary much more than just money. They may also gain much more than image, because their actions, for the benefit of narrow areas of social development, may simultaneously mean building the market, or training human resources needed for further development of the company.

The influence of family on philanthropic activities has one more facet. Research conducted by EY and Kennesaw State University shows that 81 percent of the world's largest family businesses engage in philanthropic activities [72]. The same participation in philanthropic activities is declared by Polish FBs [36]. Many of them are motivated by the desire to leave behind something more than just a sizeable bank account [60]. 
Establishing a foundation or philanthropic project named after the donor, placing the family name on a gratitude plaque (often seen, e.g., in Catholic churches in Poland), and publicly thanking or rewarding the donor for his or her service to others are important motivators for philanthropists. They build a positive image and reputation on FB that encourages people to take it up and enjoy the high social standing.

Botha [57] writes about the particular benefits of philanthropic families in continuing the culture of sharing wealth: "especially for parents and grandparents, family philanthropy can provide an attractive link between the present and the future. The experience with loved ones can be shared here and now, while a legacy of giving is built for future generations. Philanthropy alone will not right all the wrongs in this world, but with the newfound brilliance around Family Office impacts investing, it can be a gift that keeps on giving."

\section{Conclusions}

- FB owners show great sensitivity and generosity in responding to society's needs.

- One of the most significant conclusions is that social involvement derives from the values and attitudes of the owners' family, so it is an enduring value connecting generations.

- Social involvement of a single FB on a macro scale has no systemic significance, but on a micro scale, FBs are irreplaceable in their charity. The effect of scale makes this activity socially significant on a national scale as well.

- The next important observation is the positive impact of the friendly socioeconomic climate of the company's home region on FB social behavior.

- Charitable giving occurs as charity (a response to society's immediate needs) and as philanthropy (a long-term activity).

- Both the results of the conducted research and the literature studies clearly indicate that FBs' social involvement, passing on to the next generation a culture of caring for others and sharing-in particular, philanthropy_increases the chances of company and business family longevity.

- Philanthropy should be a charitable investment. That is, it should: (1) be in line with the expectations of the beneficiaries and with the profile and objectives of FB's operations, (2) be financially effective so that there is no shortage of funds for its continuation, (3) increase the prestige of FB in the community so that the successor is proud of the doyen's achievements, to take over the assets with conviction and cultivate family traditions contributing to the longevity of the company and the family.

- Social involvement of a single FB has no systemic significance; it is important only on a micro scale. However, the IBR research showed that $81 \%$ of FBs in Poland declare involvement in social activity. Taking into account the effect of scale, the donations of these companies should be considered important for sustainable social development in Poland.

- The results of the research indicate that FB owners providing support to "neighborhood beneficiaries" evaluate the rationale for providing support to them (sometimes they refuse); therefore, FB charity effectively solves social problems, rather than funding people who do not require this assistance.

- In many countries, corporate philanthropy is supported by tax policy. Currently, in Poland, it is possible to deduct from the income (revenue) the value of the donation made, but not more than the amount equal to $6 \%$ of the income. Only for the purposes of the fight against COVID-19 may a deduction be made in the full amount of the donation [73].

- If we accept that FB's social commitments are voluntary decisions by owners to share wealth, then the question arises as to whether charging a portion of that charity (the value of the tax credit) to society as a whole undermines its essence?

Funding: This research received no external funding.

Institutional Review Board Statement: Not applicable. 
Informed Consent Statement: Not applicable.

Data Availability Statement: Not applicable.

Conflicts of Interest: The author declares no conflict of interest.

\section{References}

1. Gąsiorowski, M. Od Rzemieślnika do Businesswoman. Irena Eris: Nagle Zobaczyłam, że Mogę Się Rozwijać. Business Insider Polska. Available online: https:/ / businessinsider.com.pl/firmy/dr-irena-eris-o-swojej-firmie-i-drodze-do-sukcesu/59ywbl3 (accessed on 16 March 2021).

2. Kulczyk, D. Moje Pomaganie Nie Jest FANABERI BOGATEJ Dziewczyny. Available online: https://www.pudelek.pl/ dominika-kulczyk-o-swej-filantropii-moje-pomaganie-nie-jest-fanaberia-bogatej-dziewczyny-6551202461563712a (accessed on 4 June 2021).

3. Mori, N.; Goodluck, C. The Role of Boards of Directors of Family-Owned Microfinance Institutions: Lessons from the Boardroom. J. Family Bus Manag. 2018, 9, 79-97. [CrossRef]

4. Piszczek, A. Firma Rodzinna-Duma Czy Wstyd? Mag. Firm Rodz. 2018, 5, 3-4. Available online: https://firmyrodzinne.pl/wpcontent/uploads/2018/10/Relacje_32,October2018_web.pdf (accessed on 25 April 2021).

5. Habbershon, T.G.; Williams, M.L. A Resource-Based Framework for Assessing the Strategic Advantages of Family Firms. Fam. Bus. Rev. 1999, 12, 1-25. [CrossRef]

6. Jin, K.; Lee, J.; Hong, S.M. The dark side of managing for the long run: Examining when family firms create value. Sustainability 2021, 13, 3776. [CrossRef]

7. De Massis, A.; Frattini, F.; Majocchi, A.; Piscitello, L. Family firms in the global economy: Toward a deeper understanding of internationalization determinants, processes and outcomes. Glob. Strategy J. 2018, 8, 3-21. [CrossRef]

8. Botero, I.C.; Cruz, C.; De Massis, A.; Nordqvist, M. Family Business research in the European Context. Eur. J. Int. Manag. 2015, 9 , 139. [CrossRef]

9. Grant Thorton. Rodzinny Biznes na Giełdzie. Analiza Spółek Rodzinnych Notowanych na Giełdzie Papierów Wartościowych w Warszawie; Fundacja Firmy Rodzinne: Wronki, Poland; GPW: Warsaw, Poland, 2018; pp. 16-40.

10. Bielawska, A. Firmy Rodzinne-Dylematy Definicyjne. In Wybrane Problemy Finansów Publicznych i Przedsiębiorstw; Wasilewski, M., Bereźnicka, J., Eds.; SGGW: Warsaw, Poland, 2020; pp. 15-22.

11. Kunz, P.V. Familienunternehmen in der Schweiz-Herausforderungen sowie Lösungsmöglichkeiten. Expert Focus Schweiz. Z. Wirtsch. Steuern Rechn. Wirtsch. 2018, 92, 449-456.

12. Zellweger, T. Managing the Family Business Theory and Practice; EE Edward Elgar Publishing: Cheltenham, UK; Northampton, MA, USA, 2017; pp. 4-22.

13. Bratnicka-Myśliwiec, K. Bogactwo Społeczno-Emocjonalne i Twórczość Organizacyjna w Przedsiębiorstwie; Wydawnictwo Uniwersytetu Ekonomicznego w Katowicach: Katowice, Poland, 2019; pp. 51-52.

14. Sirmon, D.G.; Hitt, M.A. Managing Resources Linking Unique Resources Management and Wealth Creation in Family Firms. 2003. Available online: https:/ / www.researchgate.net/publication/228171414 (accessed on 20 April 2019).

15. Klein, S.B. Family Businesses in Germany: Significance and Structure. Fam. Bus. Rev. 2000, 13, 157-181. [CrossRef]

16. The Henokiens International Association of Bicentenary Family Companies. Available online: https://www.henokiens.com/ content.php?id=4\&lg=en (accessed on 12 May 2021).

17. Bain, D. What Makes a Company Survive More Than 100 Years? Family Capital. Available online: https://www.famcap.com/20 21/04/what-makes-a-company-survive-more-than-100-years/ (accessed on 7 April 2021).

18. Jaffe, D. The Healthier the Family, the Stronger the Business. Leadership Is Not Just for Work. Available online: https: / / innerwill.org/family-business/ (accessed on 25 March 2021).

19. Lee, J. Family firm performance: Further evidence. Fam. Bus. Rev. 2006, 19, 103-114. [CrossRef]

20. Ramadani, V.; Hoy, F. Context and uniqueness of Family Business. In Family Businesses in Transition Economies; Springer: Berlin/Heidelberg, Germany, 2015. [CrossRef]

21. Franco, M.; Piceti, P. Family dynamics and gender perspective influencing copreneurship practices: A qualitative analysis in the Brazilian context. Int. J. Entrep. Behav. Res. 2018, 26, 3-22. [CrossRef]

22. Schraml, S.C. Finanzierung von Familienunternehmen: Eine Analyse Spezifischer Determinanten des Entscheidungsverhaltens; Springer: Gabler/München, Germany, 2009; pp. 21-108.

23. Madej, J. Marco z Gliwic to Firma Marzeń. Jej Szef Lubi Prawdziwie Dobre Zmiany. Available online: https: / / katowice.wyborcza. pl/katowice/1,35055,20022807,marco-z-gliwic-to-firma-marzen-jej-szef-lubi-prawdziwie.html (accessed on 12 May 2021).

24. Gómez-Mejía, L.R.; Haynes, K.T.; Núñez-Nickel, M.; Jacobson, K.J.L.; Moyano-Fuentes, J. Socioemotional wealth and business risks in family-controlled firms: Evidence from spanish olive oil mills. Adm. Sci. Q. 2007, 52, 106-137. [CrossRef]

25. Jaffe, D. If You Want Your Family Business to Last Several Generations. FORBES. Available online: https://www.forbes. com/sites/dennisjaffe/2018/08/30/if-you-want-your-family-business-to-last-several-generations/\#7e756d4a7c16 (accessed on 20 May 2021).

26. Litz, R.A. The Family Business: Toward Definitional Clarity. Fam. Bus. Rev. 1995, 8, 71-81. [CrossRef] 
27. Cabrera-Suarez, K.; De Saa-Perez, P.; Garcia-Almeida, D. The succession process from a resource-and knowledge-based view of the family firm. Fam. Bus. Rev. 2001, 14, 37-48. [CrossRef]

28. O Biznesie Rodzinnym Głosem Sukcesorów. Kacper Sosnowski. Available online: https://www.pwc.pl/pl/publikacje/2018 /nextgenstudy2018/kacper-sosnowski-kross.html (accessed on 5 May 2021).

29. Popczyk, W. Modele sukcesji zarządzania w przedsiębiorstwach rodzinnych. In Zarzadzanie Strategiczne w Dobie Cyfrowej Gospodarki Sieciowe; Urbanek, G., Gregorczyk, S., Wyd, U.L., Eds.; Publishing House of the University of Lodz: Lodz, Poland, 2020; pp. 105-120.

30. Orfinger, H. Firma Rodzinna-Coś Więcej niż Zysk. Available online: https://www2.deloitte.com/pl/pl/pages/press-releases / articles/co-czwarta-firma-rodzinna-przygotowana-na-sukcesje.html (accessed on 18 August 2021).

31. Fueglistaller, U.; Zellweger, T. Die Volkswirtschaftliche Bedeutung der Familienunternehmen in der Schweiz; Serie Familienunternehmen; Schweizer Arbeitgeber: Zürich, Switzerland; Bern, Switzerland; Lausanne, Switzerland, 2007; Volume 15. Available online: https:/ / www.alexandria.unisg.ch/38756/1/PDFZellweger_Arbeitgeber.pdf (accessed on 12 May 2021).

32. Abbas, J.; Raza, S.; Nurunnabi, M.; Minai, M.S.; Bano, S. The impact of entrepreneurial business networks on firms' performance through a mediating role of dynamic capabilities. Sustainability 2019, 11, 3006. [CrossRef]

33. Abbas, J. Crisis management, transnational healthcare challenges and opportunities: The intersection of COVID-19 pandemic and global mental health. Heliyon 2021, 7, e07233. [CrossRef]

34. Azizi, M.R.; Atlasi, R.; Ziapour, A.; Abbas, J.; Naemi, R. Innovative human resource management strategies during the COVID-19 pandemic: A systematic narrative review approach. Heliyon 2021, 7, e07233. [CrossRef]

35. Local Burden of Disease HIV Collaborators. Mapping subnational HIV mortality in six Latin American countries with incomplete vital registration systems. BMC Med. 2021, 19, 4. [CrossRef]

36. Instytut Biznesu Rodzinnego. Badanie Firm Rodzinnych 2015. Polska na tle Europy Środkowo-Wschodniej i Świata; PwC Polska Sp. z o.o.: Warsaw, Poland, 2015. Available online: https://www.pwc.pl/pl/publikacje/badanie-firm-rodzinnych (accessed on 10 March 2021).

37. Deloitte Private. Firmy Prywatne-Wyzwania i Możliwości. Wydanie dla Firm Rodzinnych na Rok 2020; Deloitte: Warsaw, Poland, 2021; pp. 14-18.

38. Bendix, B. Hans Carl von Carlowitz Sylvicultura Oeconomica. Stud. Mater. Ośr. Kult. Leśn. 2014, 13, $29-40$.

39. Trzpil, I.A. Polityka Gospodarcza a Polityka Społeczna: Ujęcie Modelowe i Rzeczywistość, Doctrina; Studia Społeczno-Polityczne, 2006-2007; SGH: Warsaw, Poland, 2007; Volume 3-4, pp. 123-138.

40. López-González, E.; Martínez-Ferrero, J.; García-Meca, E. Corporate Social Responsibility in Family Firms: A Contingency Approach. J. Clean. Prod. 2019, 211, 1044-1064. [CrossRef]

41. Chiang, W.-C.; Shang, J.; Sun, L. Broad bond rating change and irresponsible corporate social responsibility activities. Adv. Account. 2017, 39, 32-46. [CrossRef]

42. Bowen, H.R. Social Responsibilities of the Businessman; Harper \& Brothers: New York, NY, USA, 2013; pp. 125-134.

43. Beckman, S.; Morsing, M.; Reich, L. Strategic CSR Communication: An Emerging Field. In Strategic CSR Communication; Morsing, M., Beckmann, S., Eds.; DJØF Publishing: Copenhagen, Denmark, 2006; pp. 11-36.

44. Altenburger, R.; Schmidpeter, R. (Eds.) Die gesellschaftliche Verantwortung von Familienunternehmen. In CSR und Familienunternehmen. Management-Reihe Corporate Social Responsibility; Springer Gabler: Berlin/Heidelberg, Germany, 2018. [CrossRef]

45. Drucker, P.F. Myśli Przewodnie Druckera; MT Biznes: Warsaw, Poland, 2011; pp. 147-156.

46. Münstermann, M. Corporate Social Responsibility Ausgestaltung und Steuerung von CSR; Springer Gabler: Wiesbaden, Germany, 2007; pp. 1-29.

47. Dyer, W.G.; Whetten, D.A. Family firms and social responsibility: Preliminary evidence from the S\&P 500. Entrep. Theory Pract. 2006, 30, 785-802.

48. Li, K.; He, C.; Dbouk, W.; Ke, Z. The Value of CSR in Acquisitions: Evidence from China. Sustainability 2021, 13, 3721. [CrossRef]

49. Carroll, A.B. Corporate social responsibility: Evolution of a definitional construct. Bus. Soc. 1999, 38, 268-295. [CrossRef]

50. ISO 26000; Guidance on Social Responsibility. Norma Międzynarodowa Dotyczaca Społecznej Odpowiedzialności; ISO: Geneva, Switzerland, 2012. Available online: https:/ / www.pkn.pl/informacje/2013/09/iso-26000 (accessed on 10 May 2021).

51. European Commission. Communication from the Commission to the European Parliament, The Council, The European Economic and Social Committee and the Committee of the Regions: A Renewed EU Strategy 2011-2014 for Corporate Social RESPONSIBILITY. 2012. Available online: https:/ / ec.europa.eu/transparency/documents-register/COM(2011)68 (accessed on 10 May 2021).

52. Carroll, A.B. The Pyramid of Corporate Social Responsibility: Toward the Moral Management of Organizational Stakeholders. Bus. Horiz. 1991, 34, 39-48. [CrossRef] 
53. Eulerich, M.; Bettermann; Robers, G.N. Das gesellschaftliche Engagement von Familienunternehmen, Stiftung Familienunternehmen (Hrsg.), Das Gesellschaftliche Engagement von Familienunternehmen, Universität Duisburg-Essen, Mercator School of Management, Lehrstuhl für Interne Revision, München 2020. Available online: https:/ /www.familienunternehmen.de/media/ public/pdf/publikationen-studien/studien/Studie_Stiftung_Familienunternehmen_Das-Gesellschaftliche-Engagement-vonFamilienunternehmen.pdf (accessed on 23 April 2021).

54. The Global Family Office Report 2019. UBS, Global Family Office, Campden Wealth. Available online: https://www.ubs. com/global/en/wealth-management/uhnw/global-family-office-report/global-family-office-report-2019.html (accessed on 23 April 2021).

55. Vogel, P.; Eichenberger, E.; Kurak, M. Family Philanthropy Navigator; IMD Schweiz: Lausanne, Switzerland, 2020.

56. Karnani, A. The Case Against Corporate Social Responsibility. “Wall Street Journal”. 23 August 2010. Available online: https:/ / www.wsj.com/articles/SB10001424052748703338004575230112664504890 (accessed on 11 May 2021).

57. Botha, F. Philanthropy and Family Offices: The Gift That Keeps on Giving. Available online: https://www.forbes.com/sites / francoisbotha/2019/01/31/philanthropy-and-family-offices-the-gift-that-keeps-on-giving/?sh=2609c8be38b4 (accessed on 21 March 2021).

58. Misciattelli delle Ripe, P. Prezes Actions Placement Agent Oraz. AIFO. Available online: http://www.comunicazioneitaliana.it/ component/jumi/utente-dettagli?uid=109280 (accessed on 21 April 2021).

59. Majchrzak, K. Filantropia korporacyjna-Granice “Dobroci”. In Kwartalnik Nauk o Przedsiębiorstwie; SGH: Warsaw, Poland, 2012; Volume 25, pp. 5-12.

60. Kulczyk, D. Filantropia to Inwestycja Społeczna. Available online: https://www.forbes.pl/przywodztwo/dominika-kulczyk-opomaganiu-i-filantropii/8ntgrl4 (accessed on 21 March 2021).

61. Rodzinna Firma, Rodzinne Wartości FR Suempol. Available online: https://suempol.pl/kontakt/]\$ backslash\$ (accessed on 1 February 2021).

62. Bieniaszewska, M. Pomagam Liderom Dotrzeć do ich Mocnych Stron i Zbudować Indywidualny Styl Przywództwa, Przedsiębiorczyni z Branży Motoryzacyjnej, Właścicielka MB Pneumatyka, Mentorka. Available online: https://malgorzatabieniaszewska.pl/ o-mnie/ (accessed on 17 May 2021).

63. FR Polpharma. FR Polpharma. Fundacja Rodziny Staraków. Available online: https://starakfoundation.org/pl/fundacja (accessed on 17 May 2021).

64. FR Roleski Historia. Społeczna Odpowiedzialność. Available online: https://www.gowork.pl/roleski-sp.-j,986065/spo \T1 $\backslash$ leczna_odpowiedzialność (accessed on 17 May 2021).

65. FR Tarczyński S.A. Przedstawia Strategię Działań CSR. Available online: https://www.hurtidetal.pl/article/art_id,31276-107/ tarczynski-s.a.-przedstawia-strategie-dzialan-csr/place,1 (accessed on 21 February 2021).

66. Fundacja Piotra Klera. Available online: https://www.kler.eu/pl/fundacja-piotra-klera (accessed on 6 May 2021).

67. JMP Flowers. Rodzina Ptaszków, Tradycyjnie Innowacyjni. Działalność Społeczna. Available online: https://jmpflowers.pl/onas/ (accessed on 17 May 2021).

68. Polska Firma Fjord Nansen Pomaga Spełniać Marzenia w Chile i na Ukrainie. Available online: https:/ / familybusiness.ibrpolska. pl/polska-firma-fjord-nansen-pomaga-spelniac-marzenia-chile-ukrainie/ (accessed on 8 March 2021).

69. Filantrop Naszych Czasów. Fundacja Pomocy Osobom Niepełnosprawnym “Filantrop". Available online: https://www.drutex. $\mathrm{pl} / \mathrm{pl} /$ aktualnosci/filantrop_roku.html (accessed on 27 March 2021).

70. Tadeusz Gołębiewski Zastawił Swój Majątek, by Ratować Hotele i Miejsca Pracy. Available online: https:/ / www.forbes.pl/biznes / hotele-golebiewski-w-czasie-koronawirusa-tadeusz-golebiewski-zastawil-majatek-by/dbnw4vj (accessed on 6 May 2021).

71. De Neve, J.E. Współautor Raportu; World Happiness Report 2021. Available online: https://tvn24.pl/biznes/ze-swiata/worldhappiness-report-2021-najszczesliwsze-panstwa (accessed on 15 May 2021).

72. Korzeniewska, A. Dlaczego Jednym Pomagamy, a Innym Odmawiamy? Available online: https://www.forbes.pl/opinie/ filantrop-co-go-motywuje-dlaczego-chce-pomagac/h5yp18d (accessed on 13 May 2021).

73. Ustawa o zmianie ustawy o podatku od spadków i darowizn. Dz. U. z Dnia, 12 October 2020; 1761. 